\title{
Assess the Knowledge Regarding Pap Smear Among Women
}

\section{Dr. V. Kumari ${ }^{1}$, Jayanthi $V^{2}$, Dr. Indira $S^{3}$, N Subhashini ${ }^{4}$}

'Professor, Narayana College of Nursing, Chinthareddypalem, Nellore, Andhra Pradesh, India 2Principal, Sree Narayana Nursing College, Chinthareddypalem, Nellore, Andhra Pradesh, India ${ }^{3}$ Principal, Narayana College of Nursing, Chinthareddypalem, Nellore, Andhra Pradesh, India ${ }^{4}$ Assistant Professor, Sree Narayana Nursing College, Chinthareddypalem, Nellore, Andhra Pradesh, India Corresponding Author: Dr. Indira S

\section{ABSTRACT}

Background: Cervical cancer screening is an essential part of women's routine health care. The Pap smear test is the way to detect abnormal cervical cells including precancerous cervical lesions as well as early stage cervical cancer.

Objectives: 1.To assess the level of knowledge regarding Pap smear among women. 2. To find out the association between level of knowledge regarding Pap smear among women with their selected socio demographic variables.

Methodology: Cross sectional descriptive research design was used to conduct research study. 30 women residing at Kamakshi Nagar in Nellore were selected by using non probability convenience sampling technique. Result: The result reveals that,out of 30 women, 17 (57\%) had in adequate knowledge, 10 (33\%) had moderately adequate knowledge and only $3(10 \%)$ had adequate knowledge regarding pap smear.

Conclusion: The study concluded that majority of women had inadequate knowledge on pap smear test .hence there is a need to conduct awareness programme in community to raise the level of awareness on pap smear test. Keywords : Knowledge, Pap smear, Women.

\section{INTRODUCTION}

Cervical cancer is the fifth most common cancer in humans, the fourth most common cancer in women worldwide. It is the most common cancer related deaths among women in the developing countries. Based on the World Health Organization (WHO) stated that, $22 \%$ of female deaths are caused by malignant tumors, out of these $18 \%$ of them are due to cervical cancer. Five screening methods namely; naked eye visual inspection of the cervix with application of diluted acetic acid (VIA), examination with Lugol's Iodine (VILI) or with a magnifying device (VIAM), the Pap smear and Human Papilloma
Virus (HPV) testing with high-risk probe of the Hybrid Capture-2 assay (HC2) is used to detect the cervical cancer in precancerous stage. Several conventional methods have been proposed for the early diagnosis of cervical cancer and its secondary prevention, out of these Pap smear test is the most effective method for screening of cervical cancer.

Pap smear test is a simple and inexpensive diagnostic method and is therefore useful especially in areas with limited resources. The diagnostic utility of cervicovaginal cytology (Pap test) as a first line of investigation has assumed importance in screening of cervical cancer. Hence the investigator selected the 
present study to identify the level of knowledge among women.

\section{STATEMENT PROBLEM}

A Study to Assess the Knowledge Regarding Pap smear among Women in Kamakshi Nagar At Nellore.

\section{OBJECTIVES}

- To assess the level of knowledge regarding pap smear among women

- To find out the association between level of knowledge regarding pap smear among women with their selected socio demographic variables

\section{METHODS AND MATERIAL}

A quantitative research approach and Cross sectional descriptive research design was used to assess the knowledge regarding Pap smear among Women in Kamakshi Nagar at Nellore. The sample includes all women who are residing in Kamakshi Nagar. 30 women were selected by using non probability convenience sampling technique.

\section{Criteria for Sample Selection Inclusion criteria}

The women in NTR Nagar, Nellore

Who are willing to participate

Who are available at the time of data collection

Who knows Telugu or English.

Exclusion criteria: Women who are

Having acute illness

Not willing to participate in the study

\section{DESCRIPTION OF THE TOOL:}

The tool consists of 2 parts.

PART-I: It deals with the socio demographic variables like age, educational qualification, occupation, income per month, religion, marital status, type of family.

PART-II : It deals with structured questionnaire comprise 26 questions based on pap smear
Score interpretation: Score of one and zero were awarded respectively to each correct and wrong answer.

\begin{tabular}{|l|l|}
\hline Level of knowledge & Percentage \\
\hline Inadequate knowledge & $<50 \%$ \\
\hline Moderately adequate knowledge & $51-70 \%$ \\
\hline Adequate knowledge & $>71 \%$ \\
\hline
\end{tabular}

Content validity was obtained from nursing academic researchers and reliability of the tool was tested by using test and retest method .The reliability coefficients for all the tool was 0.8 .

\section{DATA COLLECTION PROCEDURE:}

Prior formal permission was obtained from the institutional ethical committee, Narayana Medical College Hospital, Nellore and permission obtained from the village sarpanch. The samples were informed by the investigator about the purpose of the study and the written consent was obtained. The data collection was carried out 2 weeks. Data was collected by using socio demographic variables and a structured questionnaire was used to measure the level of knowledge regarding Pap smear. It took 1015 minutes to collect the data from each participant. The data was analyzed and tabulated by using descriptive and inferential statistics based on objectives of the study.

\section{DATA ANALYSIS}

The data analyses were performed using IBM Statistical package for social sciences (SPSS) version 20.0. Descriptive and inferential statistics were used. Socio Demographic variables are analyzed in terms of frequencies and percentages. Knowledge score about the pap smear was presented using , Mean and standard deviation. Chi square test used to determine the association between the socio demographic variables and level of knowledge among the study group. 


\section{RESULTS AND DISCUSSION}

Section-I: Frequency and percentage distribution of socio demographic variables.

Majority of patients In relation to age 13 (43.3\%) women are between $30-40$ years, In context to education $15(50 \%)$ of women had intermediate, In view to occupation $25(83.3 \%)$ are house wives, In context to income per month $18(60 \%)$ are in between 7001-9000 rupees, In relation to religion 23 (76.6\%) are Hindu religion, In context to marital status $30(100 \%)$ women are married, in context to type of family $15(50 \%)$ are belongs to joint family.

Section-II: Percentage distribution of level of knowledge regarding Pap smear among women

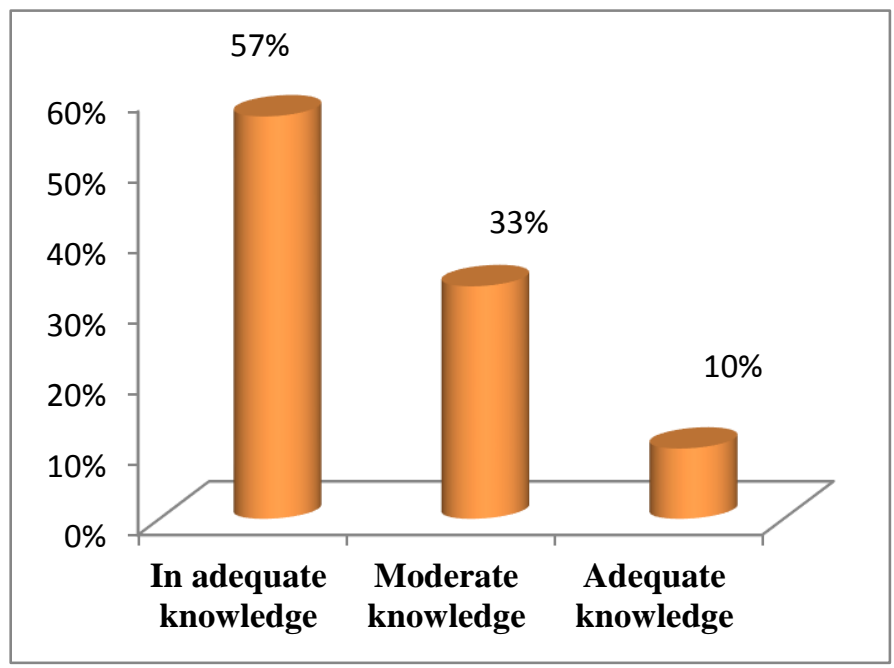

Section-III: Mean and standard deviation of knowledge regarding Pap smear among women

\begin{tabular}{|l|l|l|}
\hline Criteria & Mean & $\begin{array}{l}\text { Standard } \\
\text { deviation }\end{array}$ \\
\hline $\begin{array}{l}\text { Level of } \\
\text { knowledge }\end{array}$ & 11.5 & 2.03 \\
\hline
\end{tabular}

Section-IV : Association between the level of knowledge and socio demographic variables of women.

The Study finding reveals that there is an association between the level of knowledge regarding Pap smear test with socio and socio demographic variables like, education qualification and remaining variables has shown non significant association.

Recommendations for Further Research: On the basis of finding of the study the following recommendations are be suggested in the future research:

- A similar study can be conducted at different setting in different population

- Structured teaching programmes can be conducted to increase the awareness of women.

\section{IV.CONCLUSION}

The study concluded that, majority of the women are having inadequate knowledge about the Pap smear. Hence there is a need to conduct awareness programmes in community to improve knowledge level among public. It helps to decreases the morbidity and mortality associated with late presentation of disease.

\section{REFERENCES}

[1]. Dutta D (2003) 'Text book of obstetrics' 4th edition,New central book agency ( $p$ )Ltd page no : 316-322.

[2]. Alam M M-AS (2006) Knowledge, attitude and practice of home health care workers in the province Pap smear. J Hormozgan Univ Med Sci

[3]. Hden varency (1998) 'The text book of Midwifery '2nd edition, Black well suentific publication copy right 1980 , page no :336

[4]. Lyana y Littleton Joan c ( 2002) 'Engebreston Maternal Neonatal And Women's Health Nursing' copy right 2002 by Delmar, page no : 284-285

[5]. Varency Kibes Gegor ( 2004) 'Varencys Text Book Of Midwifery'4th edition all Indian publishers, page no : $421-422$

[6]. Phipps Long,wood 'Shafer's medical and surgical nursing '7th edition BI publications page no : 180, 527-528 
[7]. Brunner and Siddhartha's (2002) Text book of 'Medical and surgical nursing ' 10 th edition LWW publications page no :1449-1460

[8]. Dewidt LM, Incidents of cervical cancer, Journal of clinical oncology; August 2003Volume 3 Page number: 28-34.

[9]. Redman KL, Predisposition to cervical cancer in a British Population, Journal of Cancer; September 2000, Page number: 773-779.

[10]. American journal of Nursing, Volume 2, September 2000, "Pap smear" page number: 20

[11]. B. Kalpana, A study to assess the selected risk factors and incidence of cancer cervix at a selected hospital in Nellore Andhra Pradesh, Narayana Nursing Journal - Volume - 1, June 2013.

[12]. B. Kalpana, Promotion of health, Narayana Nursing Journal - Volume- 4, Issue 1, -2014.

[13]. M Naseema,P Mogileeswari, N Subhashini, Dr. Indira Arumugam. Assess the knowledge regarding risk factors of cervical cancer among nursing students in Narayana College of Nursing, Nellore. International Journal of Multidisciplinary Education and Research Volume 2; Issue 4; July 2017; Page No. 12-14.

\section{Cite this article as :}

Dr. V. Kumari, Jayanthi V, Dr. Indira S, N Subhashini, "Assess the Knowledge Regarding Pap Smear Among Women", International Journal of Scientific Research in Science and Technology (IJSRST), Online ISSN : 2395-602X, Print ISSN : 2395-6011, Volume 6 Issue 2, pp. 87-90, March-April 2019. Available at doi : https://doi.org/10.32628/IJSRST196216 Journal URL : http://ijsrst.com/IJSRST196216 